\title{
Keterkaitan Antara Pengetahuan Keuangan Dan Perencanaan Keuangan Terhadap Perilaku Keuangan Individu
}

\author{
Yohana Ika Putri dan Hendra Wiyanto \\ Program Studi S1 Manajemen Fakultas Ekonomi Universitas Tarumanagara, Jakarta \\ Email:original_hanna@yahoo.com
}

\begin{abstract}
This study aims to analyze and find out about the relationship between financial knowledge and financial planning to the financial behavior of individuals who have worked, are still working and who have a steady income who are domiciled in Jakarta. This study uses primary data in the form of questionnaires with total 100 respondents. The program used in this study is SMART-PLS version 3.2.7 using the Structural Equation Modeling (SEM) model. The results of this study are that there is no significant influence between financial knowledge on individual financial behavior and there is a positive and significant influence between financial planning on individual financial behavior.
\end{abstract}

Keywords: Finamcial Knowledge, Financial Planning, Financial Behavior

\begin{abstract}
Abstrak: Penelitian ini bertujuan untuk menganalisis dan mengetahui mengenai keterkaitan antara pengetahuan keuangan dan perencanaan keuangan terhadap perilaku keuangan individu yang pernah bekerja, masih bekerja dan yang berpenghasilan tetap yang berdomisili di Jakarta. Penelitian ini menggunakan data primer berupa kuesioner yang berjumlah 100 responden. Program yang dipakai dalam penelitian ini adalah SMART-PLS versi 3.2.7 dengan menggunakan model Structural Equation Modeling (SEM). Hasil dari penelitian ini adalah tidak terdapat pengaruh yang signifikan antara pengetahuan keuangan terhadap perilaku keuangan individu dan terdapat pengaruh positif dan signifikan antara perencanaan keuangan terhadap perilaku keuangan individu.
\end{abstract}

Kata Kunci: Pengetahuan Keuangan, Perencanaan Keuangan, Perilaku Keuangan

\section{LATAR BELAKANG}

Pada umumnya, masyarakat mengetahui pentingnya manajemen keuangan di dalam kehidupan pribadinya. Namun, masyarakat masih belum benar-benar memahami arti penting manajemen keuangan tersebut sehingga mereka masih sulit mengelola keuangan mereka dengan baik dan beranggapan bahwa perencanaan investasi keuangan hanya dilakukan oleh individu-individu yang memiliki pendapatan yang tinggi saja dan masih banyak juga individu-individu yang memiliki pendapatan yang tinggi tetapi belum melakukan perencanaan keuangan dalam pengelolaan keuangan pribadinya dengan baik (Norma Yulianti dan Meliza Silvy, 2013). Perencanaan keuangan pribadi merupakan suatu hal yang penting, karena hal tersebut merupakan proses belajar mandiri dimana setiap individu harus bisa mengatur keuangannya di masa sekarang maupun di masa yang akan datang. 
Pengetahuan keuangan menjadi hal yang tak terpisahkan dalam kehidupan seseorang, karena pengetahuan keuangan merupakan alat yang berguna untuk membuat keputusan keuangan. Namun dari pengalaman-pengalaman di berbagai negara masih menunjukkan relatif kurang tinggi karena pengetahuan keuangan yang rendah akan menyebabkan pembuatan rencana keuangan yang mungkin salah. Pengetahuan keuangan juga merupakan kebutuhan dasar bagi setiap manusia agar terhindar dari masalah keuangan (Norma Yulianti dan Meliza Silvy, 2013). Kesulitan keuangan bukan hanya fungsi pendapatan semata, kesulitan keuangan juga dapat muncul jika terjadi kesalahan dalam pengelolaan keuangan seperti kesalahan penggunaan kredit dan tidak adanya perencanaan keuangan. Keterbatasan finansial dapat menyebabkan stress dan rendahnya kepercayaan diri.

Setiap manusia mempunyai tujuan yang ingin dicapai. Tujuan hidup masing-masing individu berbeda-beda, tetapi pada umumnya adalah ingin mencapai hidup yang bahagia baik segi keuangan maupun segi lainnya. Manusia akan hidup bahagia jika sukses mencapai apa yang diinginkannya. Kesuksesan hidup manusia di dunia ini dapat diindikasikan dengan berbagai macam ukuran, seperti harta yang berhasil dikumpulkan, jenjang karir atau jabatan yang dicapainya, tingkat pendidikan yang dilalui, kesuksesan dalam usaha yang telah dicapai, penyiapan generasi penerusnya, dan kontribusinya terhadap kehidupan. Dalam bidang keuangan, manusia dikatakan sukses dan mencapai kemerdekaan keuangan, dalam arti uang sudah tidak lagi dijadikan sebagai tujuan kehidupan. Semua aktivitas dan keputusan kehidupan sudah tidak lagi semata-mata ditujukan untuk uang, tetapi uang dipandang sebagai sarana untuk mencapai tujuan yang lebih hakiki. Masih banyak hal-hal lain yang lebih menentukan kehidupan, seperti kesehatan, anak, keluarga, sahabat, dan lain-lain.

Pengetahuan keuangan juga dapat dijadikan sebagai dasar dimana setiap individu dapat mengembangkan kemampuan finansial mereka untuk mengelola keuangan mereka agar dapat berkembang dan hidup bisa menjadi lebih sejahtera di masa yang akan datang. Dan untuk mengatasi hal tersebut, maka dibutuhkanlah suatu program edukasi untuk mengelola keuangan mereka secara cerdas, agar rendahnya pengetahuan tentang pengelolaan keuangan lebih mudah diatasi dan masyarakat tidak mudah tertipu oleh berbagai produk investasi yang menawarkan keuntungan tinggi dalam jangka pendek tanpa mempertimbangkan resiko yang akan terjadi.

Selain itu, pentingnya pengetahuan keuangan bukan hanya untuk mengelola keuangan secara tepat dan cerdas, tetapi juga dapat memanfaatkan aset mereka secara bijak dan juga pengetahuan keuangan dapat menjadi nilai tambah dalam perekonomian mereka. Dengan meningkatnya pengetahuan keuangan individu maka perilaku keuangan setiap individu tersebut akan semakin lebih baik. Dengan adanya pengetahuan keuangan yang semakin membaik yang mempengaruhi tingkat perilaku keuangan dalam mengatasi keuangan mereka pun semakin membaik, maka pengelolaan dan perencanaan keuangan dari setiap individu akan terbentuk.

Perilaku keuangan yang baik ditunjukkan oleh aktivitas perencanaan, pengelolaan serta pengendalian keuangan yang baik. Indikator perilaku keuangan yang baik dapat dilihat dari cara/sikap seseorang dalam mengelola keluar masuknya uang, manajemen kredit, tabungan dan investasi (Hilgert dan Hogart, 2003). Bijak tidaknya pengelolaan keuangan pribadi ini erat kaitannya dengan kemampuan serta pengetahuan seseorang akan konsepkonsep keuangan yang dikenal dengan literasi keuangan.

Setiap individu yang memiliki pengetahuan serta kemampuan dalam mengelola keuangannya dengan baik akan menunjukkan perilaku pengambilan keputusan yang bijak 
tentang keuangan seperti kapan waktu yang tepat untuk berinvestasi, menabung, serta menggunakan kartu kredit.

Melihat uraian diatas, peneliti melakukan penelitian dengan judul " Keterkaitan Antara Pengetahuan Keuangan Dan Perencanaan Keuangan Terhadap Perilaku Keuangan”.

\section{KAJIAN TEORI}

Perilaku keuangan adalah kemampuan individu dalam mengatur perencanaan keuangan, pengelolaan keuangan, pengendalian keuangan, peranggaran keuangan, dan penyimpanan keuangan sehari-hari (Kholilah \& Iramani, 2013: 71). Munculnya perilaku keuangan karena adanya dampak besar dari hasrat individu untuk memenuhi kesejahteraan hidupnya sesuai dengan tingkat penghasilan yang diperoleh (Kholilah dan Iramani, 2013).

Salah satu teori yang dapat menjelaskan bagaimana seseorang melakukan suatu tindakan, adalah Theory of Planned Behavior. Teori perilaku terencana atau TPB (Theory of Planned Behavior) merupakan modifikasi dan perluasan dari teori tindakan beralasan atau TRA (Theory of Reasoned Action) yang telah dikemukakan oleh Fishbein \& Ajzen (1975). Konsep utama dalam Teori tindakan beralasan (TRA) adalah "prinsip-prinsip kompatibilitas" dan konsep "intensi perilaku." (Fishbein \& Ajzen, 1975; Ajzen, 1988). Menurut Ajzen \& Fishbein (1980), perilaku ditentukan oleh keinginan individu untuk melakukan atau tidak melakukan suatu perilaku tertentu dinyatakan dalam teori tindakan beralasan (TRA). Teori mengasumsikan bahwa manusia berperilaku dengan cara yang sadar maupun tidak sadar dan mempertimbangkan informasi yang tersedia (Ajzen, 1991).

Ada 4 (empat) faktor yang dihubungkan oleh teori tindakan beralasan, yaitu sikap atau attitude, keyakinan, kehendak, dan perilaku. Terdapat tiga hal yang mempengaruhi perilaku dalam pengambilan keputusan, dapat dilihat pada Gambar.1. (Ajzen, 1991).

Gambar 1. Theory of Reasoned Action

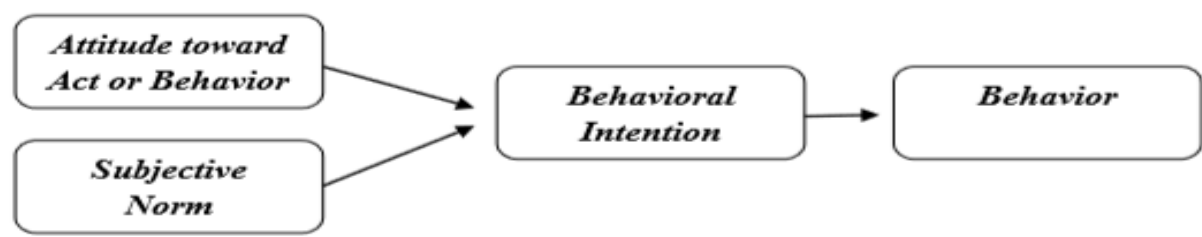

Sumber: Ajzen (1991)

Berdasarkan Gambar 2.1, dapat diketahui bahwa sikap yang spesifik mempengaruhi perilaku, norma-norma subjektif juga mempengaruhi perilaku, suatu perilaku dengan normanorma subjektif membentuk suatu tujuan berperilaku merupakan faktor yang dipengaruhi oleh perilaku dalam pengambilan keputusan yang teliti. (Ajzen, 1991).

Fishbein pada tahun 1967 memperkenalkan Theory of Reasoned Action. Teori tersebut disempurnakan selama bertahun-tahun oleh Fishbein dan Ajzen (1975). TRA dikembangkan oleh Ajzen pada tahun 1991 dengan menambahkan sebuah variabel kontrol keperilakuan yang dipersepsi, teori tersebut dikenal dengan Theory of Planned Behavior (TPB). Model TPB tersebut dapat digambarkan dalam Gambar 2.2 sebagai berikut. 
Gambar 2. Theory of Planned Behavior

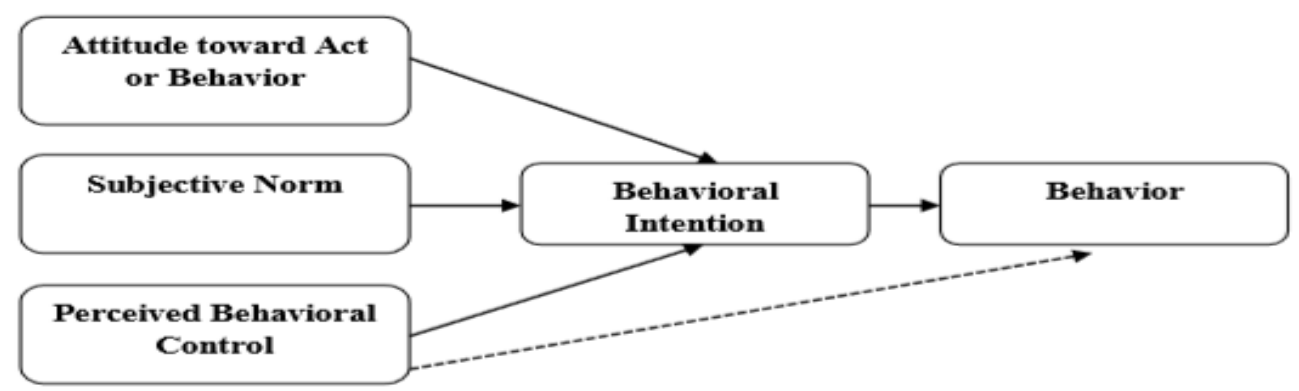

Sumber: Ajzen (1991)

Berdasarkan Gambar 2, diketahui bahwa perilaku dipengaruhi oleh niat berperilaku individu (behavior intention) terhadap perilaku tertentu menjadi faktor utama dari perilaku individu. Sikap (attitude) individu terhadap perilaku tersebut, norma subjektif (subjective norm) dan perasaan individu mengenai kemampuan mengontrol segala sesuatu yang mempengaruhi apabila hendak melakukan perilaku tersebut (perceived behavioral control) merupakan 3 (tiga) konstruk sebagai anteseden dari intense dimana untuk merencanakan teori perilaku (Ajzen, 1991).

Teori lain yang dapat menjelaskan bagaimana seseorang dapat melalukan suatu tindakan keuangan adalah Theory of Financial Literacy. Literasi keuangan merupakan kemampuan untuk membaca, mengelola keuangan, menganalisa keuangan, berkomunikasi tentang kondisi keuangan pribadi yang mempengaruhi kesejahteraan dalam materi, menghitung dan mengembangkan penilaian independen, serta mengambil tindakan yang dihasilkan dari proses-proses untuk berkembang dalam dunia keuangan secara kompleks (Vitt et al., 2000). Dari hal tersebut, dapat mencakup kemampuan dalam membedakan pilihan keuangan, mendiskusikan masalah keuangan tanpa adanya ketidaknyamanan, menanggapi kompeten, dan merencanakan masa depan untuk peristiwa-peristiwa yang mempengaruhi keputusan keuangan berjangka, termasuk peristiwa di perekonomian secara umum.

Literasi keuangan dibagi menjadi 4 dimensi, yaitu: Manajemen keuangan pribadi (Personal Finance), Bentuk simpanan di bank (tabungan, deposito, sertifikat deposito, dan giro), asuransi dan investasi (Chen and Volpe, 1998). Dalam literasi keuangan dan perilaku keuangan, ada faktor yang dipengaruhi individu, yaitu pendidikan keuangan. Pendidikan keuangan mempengaruhi literasi keuangan individu. Pendidikan keuangan memberikan pembelajaran dasar literasi keuangan, pelatihan, workshop, serta forum diskusi. Jadi, pendidikan keuangan juga mempengaruhi tingkat literasi keuangan individu juga bahkan mendapat dampak langsung kepada setiap individu dalam berperilaku dibidang keuangan individu, seperti cara menggunakan dana yang ada, serta melakukan keputusan keuangan lainnya.

Model penelitian yang akan digambarkan: 
Gambar 3. Model Penelitian

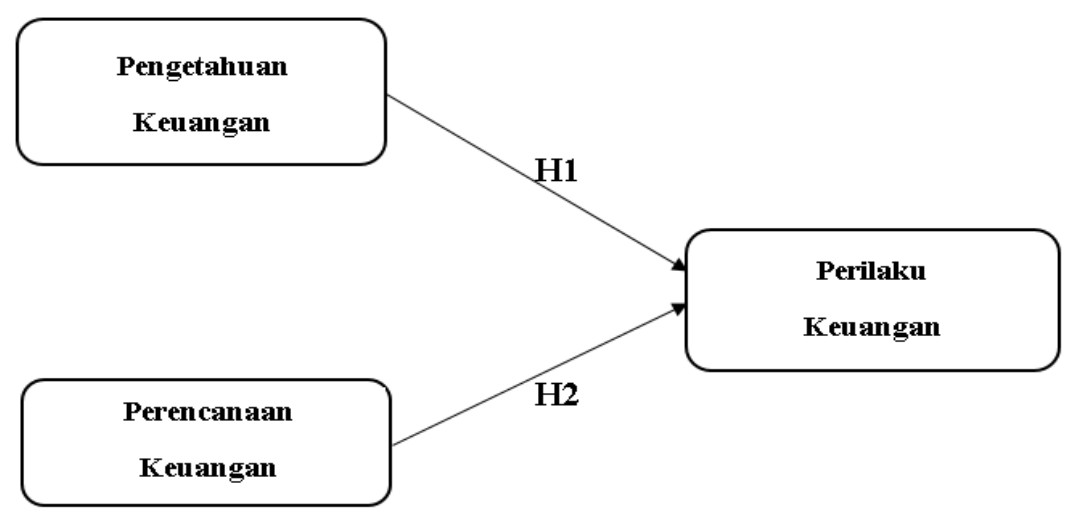

Berdasarkan model penelitian di atas, hipotesis dari penelitian ini adalah:

H1 : Adanya keterkaitan antara pengetahuan keuangand dan perilaku keuangan

H2 : Adanya keterkaitan antara perencanaan keuangan dan perilaku keuangan

\section{METODOLOGI}

Plomp (2013) menjelaskan bahwa desain penelitian atau Design Research adalah metode pembelajaran yang sistematis dimana dapat merancang, mengembangkan, dan mengevaluasi seluruh tindakan yang berhubungan dengan pendidikan, seperti proses pembelajaran, program, sistem pembelajaran, produk pembelajaran, dan bahan ajar.

Penelitian ini merupakan penelitian yang bersifat deskriptif, dimana berguna untuk mengumpulkan data atau informasi secara fakta atau tanpa dimanipulasi, aktual, dan terperinci dimana dapat dihubungkan dari 2 variabel atau lebih. Rancangan penelitian didesain untuk mengetahui hubungan atau keterkaitan antara variabel-variabel yang akan diteliti kemudian akan dianalisis lebih lanjut dengan hipotesis. Maka dari itu, penelitian ini menggunakan desain penelitian deskriptif dengan menggunakan metode penelitian crosssectional design dalam pengumpulan data, dimana data yang akan dikumpulkan dari responden hanya dilakukan 1 kali.

Populasi yang digunakan sebagai subyek dalam penelitian ini adalah individuindividu yang pernah bekerja, yang masih bekerja, dan yang berpenghasilan tetap dengan tingkat pendidikan minimal S1 di Jakarta. Desain pengambilan sampel yang digunakan dalam penelitian ini adalah desain pengambilan sampel non-probability sampling, dimana teknik pengambilan sampel tersebut dimana tidak seluruh individu dalam populasi memiliki kesempatan yang sama untuk terpilih menjadi sampel dalam penelitian. Sampel yang diambil sejumlah 100 responden. Data yang diambil merupakan data primer yaitu informasi dan data yang diperoleh secara langsung oleh peneliti berhubungan dengan variabel yang diuji untuk tujuan tertentu dari penelitian, 
Variabel pengetahuan keuangan diukur dengan 4 items, variabel perencanaan keuangan diukur dengan 5 items, dan variabel perilaku keuangan diukur dengan 4 items yang diadopsi dari Furnham (2008).

Penelitian ini menggunakan skala likert untuk mengelompokkan jawaban responden. Skala likert dalam penelitian ini dinyatakan dalam lima kategori, yaitu (1) sangat tidak setuju, (2) tidak setuju, (3) netral, (4) setuju, (5) sangat setuju.

Dalam penelitian ini, pengujian dan analisis data dilakukan dengan menggunakan perangkat lunak SMART-PLS 3.2.7.

\section{HASIL ANALISIS DATA}

Analisis validitas dilakukan dengan memperhatikan 2 hal yaitu convergent validity dan discriminant validity. Convergent Validity berhubungan dengan prinsip bahwa pengukur-pengukur (manifest variabel) dari suatu konstruk seharusnya berkorelasi tinggi. Indikator refleksif dapat dilihat dari nilai loading factor untuk tiap indikator konstruk dan kriteria Average Variance Extracted (AVE). Aturan praktis yang digunakan untuk menilai convergent validity yaitu nilai loading factor harus lebih besar dari 0,7 untuk penelitian bersifat confirmatory dan nilai loading factor antara 0,6-0,7 untuk penelitian yang bersifat exploratory masih dapat diterima. Namun untuk penelitian tahap awal dari pengembangan skala pengukuran nilai loading factor 0,5 - 0,6 masih dianggap cukup (Chin, 1998). Metode lainnya untuk mengukur convergent validity adalah Average Variance Extracted (AVE), jika nilai AVE dari variabel-variabel memiliki nilai di atas 0,5 maka telah memenuhi kriteria convergent validity (Henseler et al., 2009). Discriminant validity adalah tipe yang memiliki korelasi yang rendah dengan alat ukur lain yang mengukur atribut yang berbeda, dapat diukur melalui analisis cross-loading, dimana nilai cross-loading dari setiap indikator variabel harus lebih besar dibandingkan dengan nilai variabel lainnya dalam penelitian.

Analisis Reliabilitas dilakukan dengan menggunakan Composite Reliability dan Cronbach's Alpha. Untuk menilai reliabilitas konstruk yaitu nilai composite reliability harus lebih besar dari 0,6. Apabila seluruh nilai variabel laten memiliki nilai composite reliability $\geq 0,6$ berarti konstruk memiliki reliabilitas yang baik atau kuesioner yang digunakan sebagai alat dalam penelitian ini telah andal atau konsisten. Hasil uji reliabilitas dapat didukung oleh nilai Cronbach's Alpha yaitu harus lebih besar dari 0,6. Hasil pengujian dengan menggunakan Cronbach's Alpha pada pengetahuan keuangan sebesar 0,702, perencanaan keuangan sebesar 0,816 , dan perilaku keuangan sebesar 0,717 dan dalam penelitian dengan menggunakan composite reliability pada pengetahuan keuangan dapat dilihat bahwa hasil uji pada pengetahuan keuangan sebesar 0,819, perencanaan keuangan sebesar 0,872, dan perilaku keuangan sebesar 0,826 .

Penelitian ini menggunakan 2 model yaitu outer model dan inner model. Henseler et al. (2009) dan Hair et al. (2011) menjelaskan bahwa uji model struktural dilakukan untuk melihat kuat tidaknya suatu hubungan antar variabel di dalam model tersebut dan juga untuk menguji hipotesis yang telah dirumuskan pada penelitian dapat ditolak atau tidak ditolak. Kriteria yang harus terpenuhi dalam analisis model struktural antara lain nilai koefisien determinan $\left(\mathrm{R}^{2}\right)$, predictive relevance $\left(\mathrm{Q}^{2}\right)$, effect size $\left(\mathrm{F}^{2}\right)$ dan path coefficients.

Menurut Ghozali (2015) Nilai $R^{2}$ 0,75, 0,50, dan 0,25 dapat disimpulkan bahwa model kuat, moderate dan lemah. Perubahan nilai $R^{2}$ dapat digunakan untuk menjelaskan pengaruh variabel laten independen tertentu terhadap variabel laten dependen apakah memiliki pengaruh yang substantive. Hasil dari nilai $\mathrm{R}^{2}$ adalah 0,456 atau $45,6 \%$. Pengujian 
model struktural juga dapat dilihat dari nilai predictive relevance $\left(\mathrm{Q}^{2}\right)$ dengan ketentuan bahwa variabel dapat memprediksi model dengan baik jika nilai $\left(\mathrm{Q}^{2}\right)$ lebih besar dari nol (Hair et al., 2011). Hasil pengujian dari $\mathrm{Q}^{2}$ sebesar 0,223.

Pada path coefficients, nilainya berkisar dari -1 hingga +1 dimana +1 menduga variabel penelitian memiliki hubungan yang positif, sedangkan -1 menunjukkan hubungan yang negatif. Hasil pengujian pada path coefficients adalah nilai prediksi variabel financial knowledge terhadap financial behavior memiliki arah positif yaitu 0,163 dan nilai prediksi variabel financial planning terhadap financial behavior memiliki arah positif yaitu 0,551.

Pengukuran effect size melihat perubahan yang terjadi pada koefisien determinasi ketika variabel tertentu dieliminasi dalam sebuah model penelitian. Nilai effect size dikelompokkan menjadi 3 yaitu efek kecil $(0,02)$, efek sedang $(0,15)$ dan efek besar menunjukkan bahwa perubahan tersebut memiliki efek kecil, 0,15 untuk efek sedang, dan efek besar $(0,35)$. Hasil pengujian $\mathrm{f}^{2}$ pada pengetahuan keuangan memiliki efek perubahan sebesar 0,025 yang berarti pengetahuan keuangan memiliki efek perubahan yang kecil terhadap financial behavior. Sedangkan, pada variabel perencanaan keuangan memiliki efek perubahan sebesar 0,289 yang berarti perencanaan keuangan memiliki efek perubahan yang sedang terhadap financial behavior. Setelah itu untuk melihat nilai signifikansi pada seluruh variabel terdapat 3 kategori yaitu untuk nilai t lebih besar dari 1,65 jika $\alpha$ sebesar 10\%, nilai t lebih besar dari 1,96 jika $\alpha$ sebesar 5\% dan nilai t lebih besar dari 2,58 jika $\alpha$ sebesar $1 \%$.

Metode bootstrap dapat digunakan untuk berbagai hal, salah satunya yaitu untuk menentukan nilai T-statistics seperti yang dilakukan dalam model SEM Partial Least Square. Dengan metode bootstrap atau melakukan re-sampling sampai 5000 kali akan dapat menghitung nilai Standard Deviation sehingga selanjutnya dapat menghitung nilai Tstatistics dengan membagi koefisien regresi dengan Standard Deviation. Pengujian signifikasi dilakukan untuk mengetahui signifikansi pengaruh langsung maupun tidak langsung, dimana syarat T-statistics harus lebih besar dari T-value. T-value yang digunakan adalah 1,96 (Hair dkk., 2011). Hasil pengujian T-statistics menunjukkan bahwa nilai prediksi pada pengetahuan keuangan terhadap perilaku keuangan sebesar 1,304 dan nilai prediksi pada perencanaan keuangan terhadap perilaku keuangan sebesar 4,688.

Wetzels, Schroder, dan Oppen (2009) menjelaskan GoF dalam PLS terdapat tiga kriteria, yaitu GoF small $\left(G o F_{\text {small }}=0,1\right), \mathrm{GoF}$ medium $\left(G o F_{\text {small }}=0,25\right)$ dan GoF large $\left(\mathrm{GoF}_{\text {small }}=0,36\right)$. Penentuan kriteria GoF tersebut menggunakan nilai yang telah diperoleh dengan rumus di atas. Hasil pengujian $G o F$ sebesar 0,252168 (25,22\%).

\section{DISKUSI}

Hasil pengujian pada koefisien determinasi $\left(\mathrm{R}^{2}\right)$ sebesar 0,456 maka dapat dijelaskan bahwa variabel perilaku keuangan dapat dijelaskan oleh variabel pengetahuan keuangan dan perencanaan keuangan dan sisanya yaitu 0,544 dapat dijelaskan oleh variabel lain.

Hasil pengujian $Q$-Square $\left(\mathrm{Q}^{2}\right)$ sebesar $0,223\left(\mathrm{Q}^{2}>0\right)$, dapat dijelaskan bahwa konstruk variabel yang terdapat dalam penelitian ini relevan untuk mengukur model penelitian yang telah terbentuk sebelumnya dengan baik.

Hasil pengujian effect size dapat disimpulkan bahwa variabel pengetahuan keuangan memiliki efek perubahan sebesar 0,025 yang berarti pengetahuan keuangan memiliki efek perubahan yang kecil terhadap perilaku keuangan. Sedangkan, pada variabel perencanaan keuangan memiliki efek perubahan sebesar 0,289 yang berarti perencanaan keuangan 
memiliki efek perubahan yang sedang terhadap perilaku keuangan. Kesimpulannya, dapat diketahui bahwa setiap variabel prediktor dalam penelitian ini memiliki efek perubahan yang berarti pada tingkat struktural.

Hasil pengujian bootstrapping, maka dapat diperoleh persamaan dalam penelitian ini adalah $\mathrm{FB}=0,163 \mathrm{FK}+0,551 \mathrm{FP}$ dimana nilai path coefficients menunjukkan bahwa nilai prediksi variabel financial knowledge terhadap financial behavior memiliki arah positif yaitu 0,163 dan nilai prediksi variabel financial planning terhadap financial behavior memiliki arah positif yaitu 0,551 .

Hasil goodness of fit $(\mathrm{GoF})$ di atas, maka dapat disimpulkan bahwa model yang digunakan pada penelitian ini memiliki goodness of fit atau kecocokkan model penelitian yang tergolong sedang atau medium sebesar 0,252168 (25,22\%).

Berdasarkan hasil pengujian bootstrapping, variabel pengetahuan keuangan terbukti tidak berpengaruh terhadap perilaku keuangan individu yang pernah bekerja, individu yang bekerja, dan individu yang memiliki penghasilan tetap yang berlokasi di Jakarta. Hal ini dibuktikan dengan $t$-statistics sebesar 1,304 lebih kecil dari cut off value yang sebesar 1,96 dan p-value sebesar 0,193 lebih besar dari cut off value yang ditetapkan sebesar 0,05 sehingga dapat disimpulkan bahwa $\mathrm{H} 1$ ditolak.

Berdasarkan hasil pengujian bootstrapping, variabel perencanaan keuangan terbukti berpengaruh terhadap perilaku keuangan individu yang pernah bekerja, individu yang bekerja, dan individu yang memiliki penghasilan tetap yang berlokasi di Jakarta. Hal ini dibuktikan dengan $t$-statistics sebesar 4,688 lebih besar dari cut off value yang sebesar 1,96 dan $p$-value sebesar 0,000 lebih kecil dari cut off value yang ditetapkan sebesar 0,05 sehingga dapat disimpulkan bahwa $\mathrm{H} 2$ tidak ditolak.

\section{KESIMPULAN}

Berdasarkan dari hasil pengujian di atas, dapat disimpulkan bahwa tidak adanya keterkaitan yang terjadi antara pengetahuan keuangan terhadap perilaku keuangan yang terjadi pada individu-individu yang pernah bekerja, yang masih bekerja, dan berpenghasilan tetap yang memiliki tingkat pendidikan minimal S1. Sedangkan hasil pengujian yang telah diteliti, dapat disimpulkan bahwa adanya keterkaitan antara perencanaan keuangan terhadap perilaku keuangan pada setiap individu-individu yang pernah bekerja, yang masih bekerja, dan berpenghasilan tetap dengan tingkat pendidikan minimal S1.

Keterbatasan dalam penelitian ini adalah waktu yang relatif singkat dalam penelitian ini, maka jumlah responden dalam penelitian ini kurang dapat mempresentasikan pendapat dan tanggapan masyarakat dari segi jumlah dan area responden yang diteliti, serta adanya keterbatasan variabel-variabel yang digunakan untuk menjelaskan perilaku keuangan pada penelitian ini terbatas pada pengetahuan keuangan dan perencanaan keuangan.

Berdasarkan dalam penelitian ini, beberapa saran yang dapat diberikan oleh peneliti, yakni: (1) Peneliti menyarankan bahwa setiap individu harus mengetahui dasar dalam mengatur, mengelola, dan merencanakan keuangan pribadi secara bertanggungjawab dan bijaksana sehingga dapat membantu individu dalam mencapai kesejahteraan keuangan dan mencapai tujuan kuangan di masa yang akan datang dengan baik tanpa adanya kekhawatiran terhadap keuangan. (2) Peneliti menyarankan bahwa setiap individu yang memiliki pendapatan pribadi mulai harus melakukan pencatatan anggaran pengeluaran bulanan agar dapat merencanakan keuangan dengan baik sehingga dapat meminimalisir terjadinya 
kesulitan ekonomi di kemudian hari dan dihimbau untuk mempelajari cara bagaimana dapat mengatur keuangan pribadi dengan baik dan merencanakan keuangannya dengan baik dengan cara seperti berinvestasi atau sejenisnya dimana dapat menguntungkan keuangan pribadi secara stabil dan dapat memilah-milah pengeluaran secara tepat dan cerdas. (3) peneliti menyarankan untuk menambahkan varibel-variabel lainnya seperti financial attitude, financial experience, financial literacy, financial education, financial problem, dan lain-lain. Dan juga peneliti menyarankan untuk memberikan waktu penelitian dalam pencarian responden dilakukan lebih lama, dan memperluas area penelitian sehingga hasil penelitian yang didapat akan lebih akurat dibandingkan pada penelitian ini. (4) peneliti menyarankan untuk mengalokasikan sebagian sumber dayanya untuk memberikan edukasi keuangan kepada masyarakat mengenai pengetahuan keuangan dan cara mengalokasikan serta merencakan keuangannya dengan lebih efektif. Dengan memberikan edukasi keuangan, membantu kesadaran masyrakat dalam mengetahui pentingnya pengelolaan keuangan yang bertanggungjawab dan bijaksana, serta membantu pengelolaan keuangan yang baik seperti membuat anggaran pengeluaran, berinvestasi di pasar modal, perencanaan keuangan untuk program dana pensiun. Dengan kesadaran masyarakat juga dapat membantu meningkatkan minat masyarakat dalam berinvestasi di perusahaan, seperti perusahaan sekuritas, perbankan, dan sebagainya.

\section{DAFTAR PUSTAKA}

Ajzen, I., \& Fishbein, M. (1980). Understanding Attitudes and Predicting Social Behavior. New Jersey: Prentice-Hall. (1988). Attitudes, Personality and Behavior. Chicago: Dorsey Press. (1991). The Theory of Planned Behavior. Elsevier. Organizational Behavior and Human Decision Processes, 50, 179-211.

Chen, Haiyang and Ronal P. Volpe. (1998). An Analysis of Personal Financial Literacy Among College Students. Financial Services Review, 7 (2): 107-128.

Chin, W. W. (1998). The Partial Least Squares Approach to Structural Equation Modeling. Modern Methods for Business Research, 295-336.

Ghozali, Imam (2015) Structural equation modeling: metode alternatif dengan partial least square (PLS). Semarang: Badan Penerbit Universitas Diponegoro.

Hair, J.F., Ringle, C.M. and Sarstedt, M. (2011), PLS-SEM: indeed a silver bullet, Journal of Marketing Theory and Practice, Vol. 19 No. 2, 139-152.

Henseler, J., Ringle, C. M., \& Sinkovics, R. R. (2009). The Use of Partial Least Squares Path Modeling in International Marketing. Advances in International Marketing.

Hilgert, M.A \& Hogart M. (2003). Household Financial Management: The Connection between Knowledge and Behavior. Federal Reserve Bulletin July 2003.

Plomp, T \& Nieveen, N. (2013). Educational Design Research: An Introduction (Eds). Netherlands: SLO.

Vitt, L. A., Anderson, C., Kent, J., Lyter, D. M., Siegenthaler, J. K., \& Ward, J. (2000). Personal Finance and the Rush to Competence: Financial Literacy Education. Institute for Socio-Financial Studies, 11-18. United States.

Yulianti, Norma dan Silvy Meliza. (2013). Sikap Pengelola Keuangan Dan Perilaku Perencanaan Investasi Keluarga Di Surabaya. Journal of Business and Banking, Vol 3, 57-68. 